\title{
Aerobic Oxidation of Alcohols with $\mathrm{MoS}_{2} /$ $\mathrm{Ta}_{3} \mathrm{~N}_{5}$ Nanocomposites
}

\section{Gategory}

Polymer-Supported Synthesis

\section{Key words}

$\mathrm{MoS}_{2} / \mathrm{Ta}_{3} \mathrm{~N}_{5}$ nanocomposites aerobic oxidation alcohols

amines

sulfides

alkenes

$\mathrm{MoS}_{2} / \mathrm{Ta}_{3} \mathrm{~N}_{5} \mathrm{NPs}\left(5 \mathrm{wt} \% \mathrm{MoS}_{2}\right)$

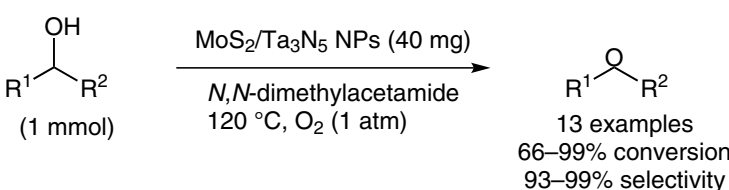

Selected results:<smiles>O=Cc1ccccc1</smiles>

$1.5 \mathrm{~h}, 85 \%$ conversion $99 \%$ selectivity<smiles>CC(C)=CC=O</smiles>

$3.0 \mathrm{~h}, 66 \%$ conversion $99 \%$ selectivity<smiles>COc1ccc(C=O)cc1</smiles><smiles>O=C1C=CCCC1</smiles>

$3.0 \mathrm{~h}, 78 \%$ conversion $99 \%$ selectivity<smiles>O=Cc1ccc([N+](=O)[O-])cc1</smiles>

$3.0 \mathrm{~h}, 86 \%$ conversion $99 \%$ selectivity<smiles>C#CC(=O)c1ccccc1</smiles>

$3.0 \mathrm{~h}, 99 \%$ conversion $98 \%$ selectivity<smiles>O=C/C=C/c1ccccc1</smiles>

$1.5 \mathrm{~h}, 99 \%$ conversion $93 \%$ selectivity<smiles>CCCC=O</smiles>

$4.0 \mathrm{~h}, 80 \%$ conversion $99 \%$ selectivity

Oxidation of amines, sulfides, and alkenes<smiles>Cc1ccc(CN)cc1</smiles>

$(1 \mathrm{mmol})$<smiles>COc1ccccc1</smiles>

(1 mmol) $\mathrm{MoS}_{2} / \mathrm{Ta}_{3} \mathrm{~N}_{5} \mathrm{NPs}(40 \mathrm{mg})$

\section{Selected results:}<smiles>Cc1ccc(/C=N/Cc2ccc(C)cc2)cc1</smiles>

$3.0 \mathrm{~h}, 52 \%$ conversion $99 \%$ selectivity<smiles>CS(=O)c1ccccc1</smiles>

$3.0 \mathrm{~h}, 50 \%$ conversion $99 \%$ selectivity
$\mathrm{N}, \mathrm{N}$-dimethylacetamid $120^{\circ} \mathrm{C}, \mathrm{O}_{2}(1 \mathrm{~atm})$

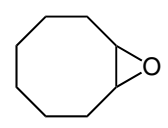

$6.0 \mathrm{~h}, 49 \%$ conversion $94 \%$ selectivity
Significance: $\mathrm{Ta}_{3} \mathrm{~N}_{5}$ nanoparticles partly coated with a $\mathrm{MoS}_{2}$ layer ( $\mathrm{MoS}_{2} / \mathrm{Ta}_{3} \mathrm{~N}_{5} \mathrm{NPs}$ ) were prepared by hydrothermal treatment of $\mathrm{Ta}_{3} \mathrm{~N}_{5} \mathrm{NPs}$ with $\left(\mathrm{NH}_{4}\right)_{6} \mathrm{Mo}_{7} \mathrm{O}_{24}$ in the presence of thiourea (eq. 1). $\mathrm{MoS}_{2} / \mathrm{Ta}_{3} \mathrm{~N}_{5}$ NPs catalyzed the aerobic oxidation of alcohols under oxygen (1 atm) to give the corresponding aldehydes or ketones in up to 99\% conversion with 99\% selectivity (13 examples, eq. 2).

SYNFACTS Contributors: Yasuhiro Uozumi, Hiroaki Tsuji Synfacts 2013,9(2), $0221 \quad$ Published online: 18.01.2013 Dol: 10.1055/s-0032-1318049; Reg-No.: Y15112SF
Comment: $\mathrm{MoS}_{2} / \mathrm{Ta}_{3} \mathrm{~N}_{5}$ NPs were characterized by SEM, TEM, XRD, ICP-AES and elemental analysis. The catalyst also promoted the aerobic oxidation of amines, sulfides, and alkenes to afford the corresponding imines, sulfoxides, and epoxides (eq. 3). In the oxidation of benzyl alcohol, the catalytic activity of $\mathrm{MoS}_{2} / \mathrm{Ta}_{3} \mathrm{~N}_{5}$ NPs was superior to that of $\mathrm{Ta}_{3} \mathrm{~N}_{5}$ NPs and $\mathrm{MoS}_{2}$. 